\title{
LEARNING AND TEACHING OF ENGLISH IN A FOREIGN LANGUAGE CLASSROOM OF PRIMARY EDUCATION THROUGH CURRENT SONGS AND CARTOONS
}

\author{
Natalia Lucía Vélez Gea, Universidad de Almería ${ }^{1}$ \\ Email: natalia_vg_@hotmail.com
}

\begin{abstract}
The main purpose of this study is to suggest a series of materials related to English teaching as a foreign language, suitable for the second cycle of Primary Education students. To be able to do this, three songs and three episodes of current cartoons have been chosen because of the students' familiarity with the materials, they will be motivated and enjoy learning. In relation to this, a variety of activities based on pre-watching/ listening, while-watching/listening and post-watching/listening have been developed. Keywords: motivation, materials, activities, cartoons, song, learning-teaching process.
\end{abstract}

Title in Spanish: Enseñanza-Aprendizaje del Inglés como Lengua Extranjera en la clase de Educación Primaria a través de canciones y dibujos animados actuales.

Resumen: El objetivo de este trabajo consiste en proponer una serie de materiales para la enseñanza del inglés como lengua extranjera, dirigida a estudiantes de segundo ciclo de educación primaria. Para ello se han elegido tres canciones y tres capítulos de dibujos animados actuales, que por su cercanía con el alumnado resultan divertidos y motivadores para el aprendizaje. En torno a ellos se han desarrollado una serie de actividades basadas en pre-watching/listening, while-watching/listening and post-watching/listening.

Palabras clave: motivación, materiales, actividades, dibujos animados, canciones, proceso enseñanza-aprendizaje.

\section{INTRODUCTION}

Many years ago, the learning of English was widely criticized because teachers' methods were not based on learning a language with the outcome to achieve communicative competence. The main objective focused mainly on acquiring grammar rules and completing written tasks in order to pass an exam. The aim of this paper is to show how students of Primary Education are able to learn English through songs and cartoons by using all the language skills, reading, writing, listening, speaking and talking.

My intention is to show how songs and cartoons can have important benefits in the teaching-learning of a foreign language. More particularly, my objectives are the following: to teach English in an amusing way, to transmit the desire and motivation of learning English

Date of reception: 4 July 2013

Date of Acceptance: 23 October 2013 
through current songs and cartoons and to design activities to be developed in the English classroom in the second cycle (third and fourth year) of Primary Education.

\subsection{METHODOLOGY AND CORPUS}

The methodology employed in my proposals to teach English through songs and cartoons is varied, flexible and based on the students' needs and interests. I will introduce different activities to be carried out in three steps: Pre-Activity, which goes before watching the cartoons or listening to the song whose aim is to help students in the process of understanding the theme or story of the song/cartoon; While-Activity, which takes place while the students are watching the cartoon or listening to the song. This aim is to maintain the students' interest and Post-Activity, which comes after carrying out the activity in order to evaluate the students' comprehension of the video or the song.

The activities that I introduce are related to the development of the five educational skills, according to the European Common Framework of Reference for languages (CEFR) (2001), they are:

Listening: It is believed that listening is a passive skill but this is not really true because when two people are talking, the transmitter has to know if the receiver has understood the information, so the transmitter will know if the person listening has understood the message by gestures, movements or nods. According to Harmer (2007), listening activities are divided in three steps: pre-listening, while-listening and post-listening. Therefore, I have included activities to cover these three steps for each presentation.

Reading: Reading is the process of decoding symbols in order to construct meaning. Students have to acquire knowledge about morphemes, words and sentences. It is a passive skill. It is important to read in a concrete rhythm because if children read too fast or too slow they are not going to understand the text. According to Alburquerque (1990) reading activities are classified in three stages: pre-reading, while-reading and post-reading. Throughout the activities, students will be given opportunities to read along and re-affirm pronunciation of unknown words.

Writing: Writing is the representation of language in a textual medium through the use of a set of signs or symbols. To write is to create meaning in a printed way; it is not a passive skill. Alcaraz Varó (1992) defends that writing is an uneasy skill because there are lots of components: phoneme-grapheme, plurals, feminine nouns or irregular verbs. Brewster (1991) tells that there are two sorts of activities, based on words and sentences. Due to this reason, I have included age-related writing tasks for each presentation.

Speaking and talking: Speaking is practiced, according to Byrne (1989) in three stages: presentation, practice, and production. According to CEFR (2001) there is a distinction between these two terms. Speaking is to produce sound while talking is to produce sound and be understood. Our aim as teachers is to help students to achieve communicative competence and practicing talking. Brown (2000) affirms that thanks to fluency and good usage of the language in real contexts, communicative objectives are best achieved. Some people who study English like a second language affirm that developing the fifth skill ought to be one of their primary goals of study. For this reason, the activities that I have chosen to listen to and watch all practice clear and distinctive pronunciation in general practice.

My corpus consists of the following songs and cartoons: 
I have chosen the song "Every teardrop is a waterfall” by the group Cold Play which was released in 2011 in the UK, because they have a social commitment with the poor and their songs contains lyrics about problems in current society. This is why the teacher can work with these themes with confidence that children will be able to empathise with present problems of our world. Children will also be motivated in the classroom by Coldplay's songs because they are well-hnown worldwide and their songs are very popular on the music channels, such as MTV from America or 40 principales in Spain.

I have chosen the song "Superstar" by Madonna which was released in 2012 in the USA because she is a very famous singer, her pronunciation is clear and it is easy to understand her lyrics. The chorus is repetitive and rhythmic. This song permits children to know famous people and children will learn about good and bad superstars.

I have chosen the song "Bad behaviour" by Jedward which has been released in Ireland in 2011. They are very famous in Ireland and they have represented Ireland twice in the Eurovision Song Contest. The song is very rhythmical and fast, its lyrics are easy to understand and students are motivated by the theme "bad behaviour". This theme allows them to work with the behaviour values and the necessity to respect the rules.

I have chosen the second episode, "The missing piece", of the fourth season by Dora the explorer, because she is a bilingual girl universally famous, she speaks English and teaches some words and expressions in Spanish. But in Spanish-speaking countries, she teaches English, the main character is a funny girl who likes to discover new adventures. She is respectful to the environment, she repeats the vocabulary through simple songs (lake, tunnel, rainbow), it can be used in classrooms to explore topics such as caring for the environment and co-operation.

I have chosen the episode fifty-one, "A little something between friends", of the first season by Pocoyó because it is very famous amongst children. The characters often use non-verbal language and instead they use sounds and gestures. A voice-over (the narrator) explains the story of these simple plots. Thanks to this episode, teachers can work with themes such as friendship, the reconciliation of a friendship, the role of the mediator, the value of the game and also work with the vocabulary of toys.

I have chosen the forty-ninth episode, "Peppa goes shopping", of the first season by Peppa Pig because it is popular amongst children, the characters are animals and in general children like animals and they will learn food vocabulary.

\section{STATE OF THE ART}

\subsection{Previous studies of songs and cartoons}

While the study of songs and cartoons is not necessarily a new concept, the adoption rate of this methodology has been very low until quite recently here in Spain. These concepts have been popular throughout other parts of Europe, including the United Kingdom, Germany and Holland, and have proven to be effective in the advancement of a foreign language.

Some authors have conceived the importance of songs as a resource in the teaching-learning process of a second or foreign language. For example, Strachey (1950) affirms that songs can be used to improve the pronunciation, grammar rules, and vocabulary easily. Moreover, Dakin 
(1968) published a collection of one hundred and thirty two rhymes and typical English songs, classified depending on grammar structures, vocabulary, rhythm or intonation.

Some years later, Murphy (1990 and 1992) affirms that songs are an important element in the teaching-learning process along the history of the foreign languages and Griffee (1992) published a book including the contents of English language songs to be exploited in the classroom. In the same year, Cranmer and Laroy (1992) emphasized on the use of music in the foreign language classroom like an affective resource. Edwards (1997) also compares the manners and possibilities of teaching English with songs in the teaching of English like a second language. Furthermore, he affirms that songs are a good didactic resource in the teaching of second languages.

Other researchers like Holmes and Moulton (2001) agree with the idea that children learn better when they learn English through songs and poems. They say that songs and poems are kept in the mind and heart.

In Spain, some researchers also highlight the advantages of songs in a foreign language classroom. The majority of them point out the importance of songs in the oral comprehension and expression. Some of them are Robinson (1986), González de Castejón (1989), Williamson (1989), Madrid et al. (1990) and Mata (1990). Muros et al. (1998) introduce students to the music world so as to improve the linguistic capacities of the foreign language. Olivares (2002) and Fonseca (1999) defend the music like a didactic resource in the classroom.

Daniel Madrid and Neil McLaren (2004:400) maintain:

Songs are one of the most interesting resources that can be introduced in the English classroom. Students are exposed to authentic material in an enjoyable way. Through songs we can integrate all the skills and develop discourse competence while fostering our students' motivation towards the learning of the foreign language (FL).

According to the use of video in foreign language classroom Mekheim (2011) maintains that from 1970 to the present time, video is widely available as a teaching resource. Researchers and educators have asserted the importance of incorporating video material in the learning of foreign language. Different researchers have developed this idea such as Cambre et al. (1992), Secules et al. (1992) and Swaffar \& Vlatten (1997). Terrell (1993) explains the use of videos for integrated language learning. Han (1994) exposes that there are some researchers supporting the idea that the use of video can help students to improve listening and speaking. Hanley et al. (1995) remark the benefits of the use of video improving even the writing skill. Likewise, Herron et al. (1995) and Wen (1989) achieve that students are more motivated and interested in the classroom if videos are used in class. Furthermore, Kerridge (1982) affirms that the use of video as a resource in foreign language classroom (FLC) gives students the opportunity to be in contact with the culture and the communication of native speakers. Moreover, Morley (1981) defends that using videos have to be integrated in the activities of the FLC. Finally, Barrios Espinosa (2007) shows some ideas using videos to have a motivated classroom in the learning-teaching process of a foreign language. She exposes that videos permit a different way to entertain teaching children with a clear context in which teacher practice many aspects of vocabulary, 
structures, functions and socio-cultural contents. She adds that visual information permits students an easy comprehension. An image often calls more attention that a sound.

\section{PROPOSALS TO LEARN ENGLISH AS A FOREIGN LANGUAGE IN PRIMARY EDUCATION THROUGH CURRENT SONGS AND CARTOONS}

\subsection{Songs}

\section{A) COLDPLAY: "EVERY TEARDROP IS A WATERFALL" \\ Pre-listening:}

There would be a brainstorming about Coldplay music group.

\section{While-listening:}

Children will listen the song (4:00 minutes) and they will practise it through tasks.

1. Listen to the song and underline the words that you hear:

$\begin{array}{ll}\text { - people } & \text {-comma } \\ \text { - telephone } & \text { - luggage } \\ \text { - music } & \text { - dance } \\ \text { - party } & \text { - village } \\ \text { - teardrop } & \text { - heart } \\ \text { - singer } & \text { - day }\end{array}$

2. Listen to the song again and fill in the gaps with the correct words: music, you, flag, comma, dance, favourite

I turn the music up, I got my records on

I shut the world outside until the lights come on

Maybe the streets alight, maybe the trees are gone

I feel my heart start beating to my song

And all the kids they , all the kids all night

Until Monday morning feels another life

I turn the music up

I'm on a roll this time

And heaven is in sight

I turn the up, I got my records on

From underneath the rubble sing a rebel song

Don't want to see another generation drop

I'd rather be a than a full stop

Maybe I'm in the black, maybe I'm on my knees

Maybe I'm in the gap between the two trapezes

But my heart is beating and my pulses start

Cathedrals in my heart

As we saw oh this light

I swear , emerge blinking into

To tell me it's alright

As we soar walls,

every siren is a symphony 
And every tear's a waterfall

Is a waterfall

$\mathrm{Oh}$

Is a waterfall

Oh oh oh

Is a is a waterfall

Every tear

Is a waterfall

Oh oh oh

So you can hurt, hurt me bad

But still I'll raise the

$\mathrm{Oh}$

It was a wa wa wa wa wa-a-terfall

A wa wa wa wa wa-aterfall

Every tear

Every tear

Every teardrop is a waterfall

\section{Post-listening.}

1. Students are going to learn the song with "Total Physical Response" method. These are the actions:

I turn the music up $\rightarrow$ Students will imitate that they turn the volume up of a song. Maybe the trees are gone $\rightarrow$ Students will wave good-bye with the left hand.

I feel my heart start beating $\rightarrow$ Students will make a heart with their hands and will do as if the heart which is made by their hands is beating.

And all the kids they dance $\rightarrow$ They will move their hips to the right and to the left quickly.

Sing a rebel song $\rightarrow$ Students will put their hand up and make a rebel face.

Don't want to see $\rightarrow$ Students will touch their left eye and move their finger saying no.

Generation drop $\rightarrow$ Students will do thumbs down.

I'm on my knees $\rightarrow$ Students will kneel down quickly.

Two trapezes $\rightarrow$ Students will show two fingers (ring finger and index finger).

And every tear's a waterfall $\rightarrow$ Students will do like crying.

Hurt me bad $\rightarrow$ Students will stick their tongue out of the mouth, similar when people die in cartoons, and they will close their eyes.

But still I'll raise the flag $\rightarrow$ Students will get a flag (made a day before), and they will flutter it.

2. Students will watch the video clip on the screen. They can sing and dance. It lasts 4:10 minutes.

\section{B) MADONNA: "SUPERSTAR"}

\section{Pre-listening:}

1. Before listening to the song, each student will speak about her/ his favorite superstar.

2. I will give them the lyrics of the song "Superstar" by Madonna. They will read it. 


\section{While-listening:}

1. Students will listen to the song twice with the lyrics. It lasts 3:54 minutes.

2. The students have to put in order three paragraphs of the lyrics of the song, while they listen to it.

You're Bruce Lee with the way that you move

You're Travolta getting into your groove

You're James Dean driving in your fast car

You're a hot track, you're my suppa duppa star

You're like Brando on the silver screen

You're my hero in a mythical dream

You are perfect just the way that you are

You're Mike Jordan, you're my superstar

---.

You're my gangster

You're like Al Capone

You're like Ceasar

Stepping onto the throne

You're Abe Lincoln

Cuz you fight for what's right

You're my angel Bringing peace to my life

\section{Post-listening:}

1. The students are going to play in pairs. I will give them two cards. On the first one there are some questions that students have to answer asking her/his partner. The other one has the information about the different superstars that they have listened to in the song. The information is the full name, the date of birth and the job.
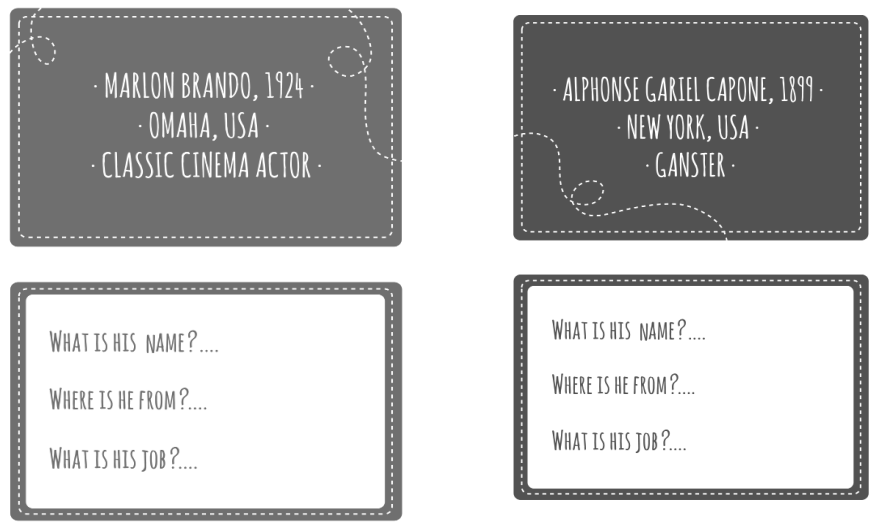

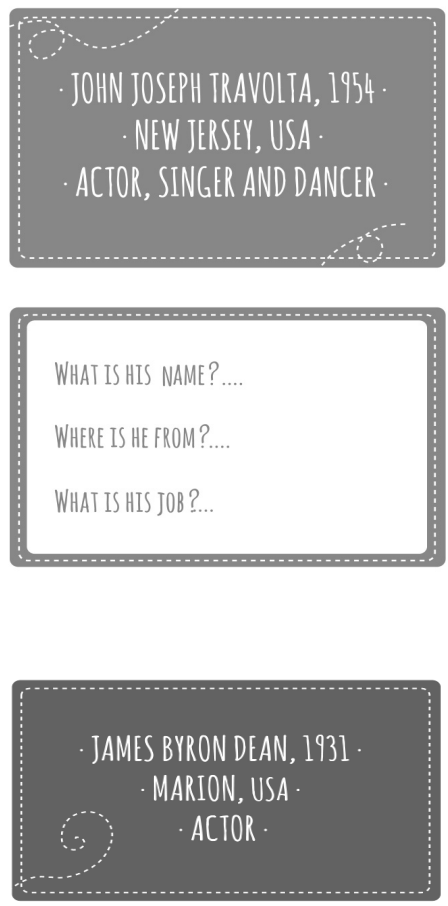

WHAT IS HIS NAME? ...

WHERE IS HE FROM?...

WHAT IS HIS JOB? .
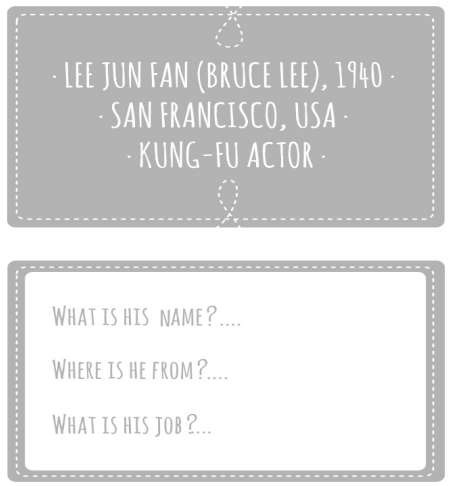

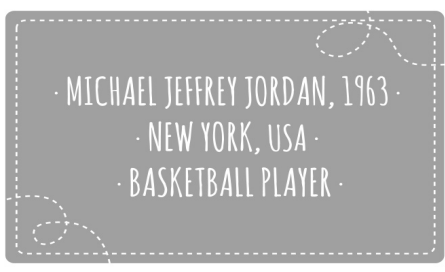

WHAT IS HIS NAME?....

WHERE IS HE FROM?...

WHAT IS HIS JOB?...

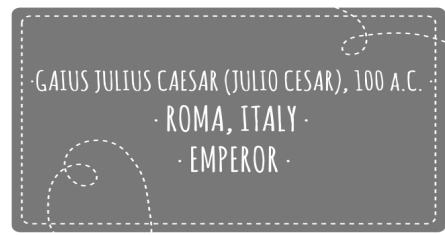

WHAT IS HIS NAME? ...

WHERE IS HE FROM?...

WHAT IS HIS JOB?

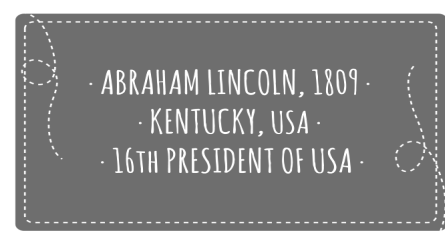

WHAT IS HIS NAME? ...

WHERE IS HE FROM?...

WHAT IS HIS JOB? 
2. Separate the letters of the lyrics. (Then they will listen to the song with the lyrics and they will keep up the beat of the song by clapping their hands while the strongest musical stress is heard (4/4).)

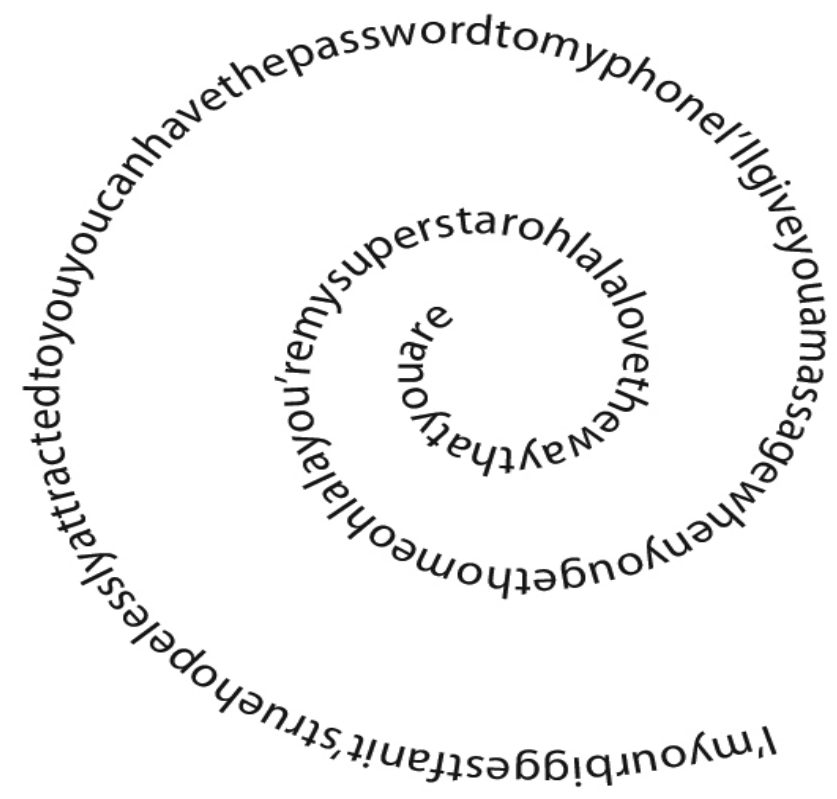

\section{C) JEDWARD: "BAD BEHAVIOUR"}

\section{Pre- listening:}

1. I will explain the meaning of "BAD BEHAVIOUR", and then the students will raise their hands up to present an example of bad behaviour. Moreover, they will tell what happened at home when they have been badly behaved.

\section{While-listening:}

The students will listen to the song twice. It lasts 2:54 minutes.

1. They have to draw a picture to represent what they are hearing.

\section{Post-listening:}

1. I will give them a work sheet with some questions about the song that they have to answer.

- What is the twins' problem?

- If there is a smile, would it be the last one? 
- Is the problem solved?

- Is it a big problem or a little problem?

3. Game: "Chinese whispers". The children have to stand up and wait in a line. There will be four groups (depending on the ratio). The game starts when I shout START! Each first student has to create a sentence starting by "I was badly behaved when..." In his/her group, the first student will say the sentence to the second, the second to the third... when the sentence arrives to the last child (should be said correctly), he/ she has to say it loudly. If the sentence is correct, this group will win.

4. I will play the video clip in class, and after watching it, the students have to describe the twins and what they have watched in the video.

\subsection{Cartoons}

\section{A) DORA THE EXPLORER}

Students are going to watch the chapter "The missing piece" from Dora the explorer.

\section{Pre-watching:}

1. Before watching the chapter, I will show to the students some flashcards with vocabulary about the episode. Students will try to guess the word which corresponds with the picture. The student who says a correct flashcard word will receive a positive point.

These are the flashcards: 

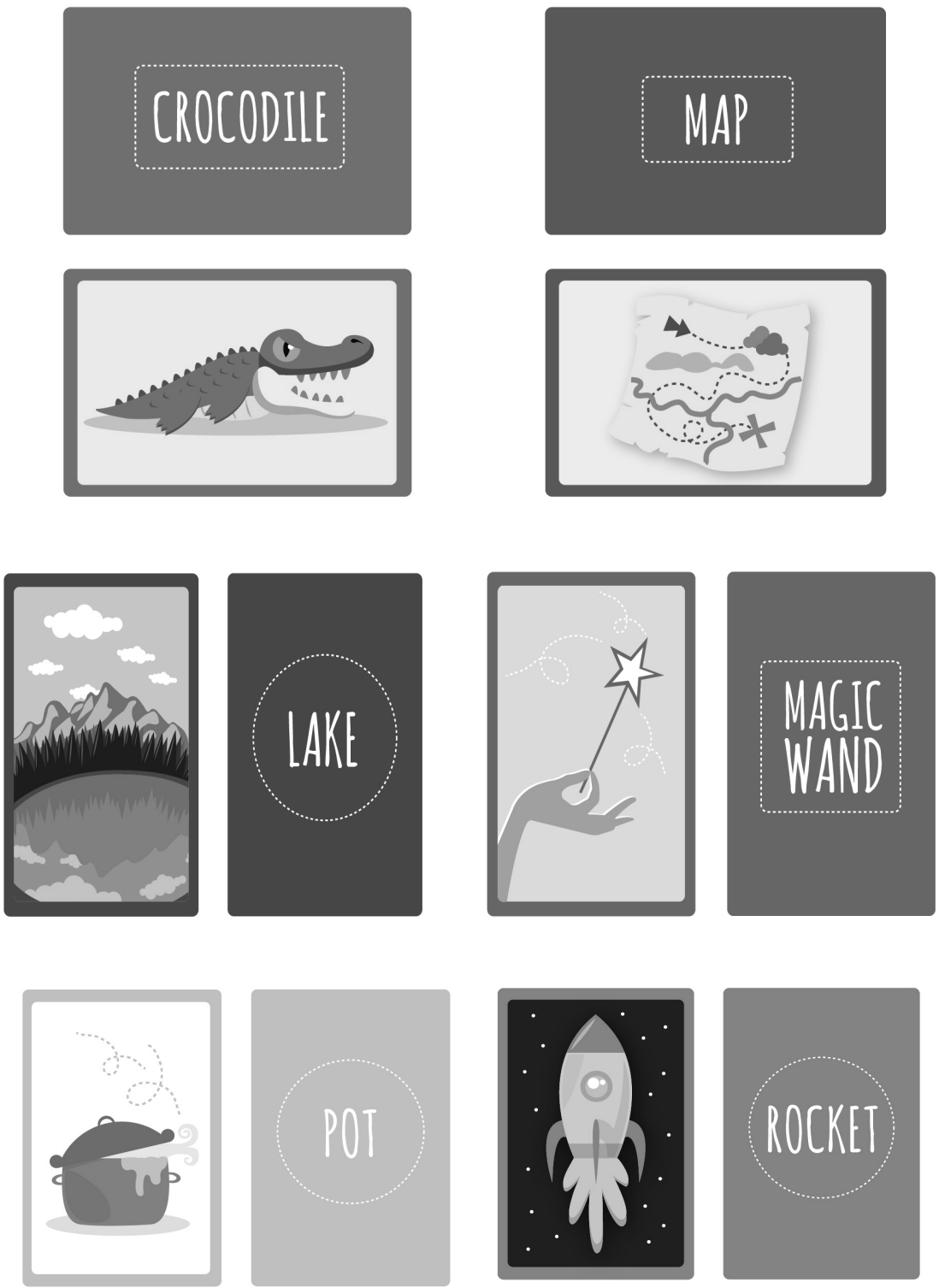

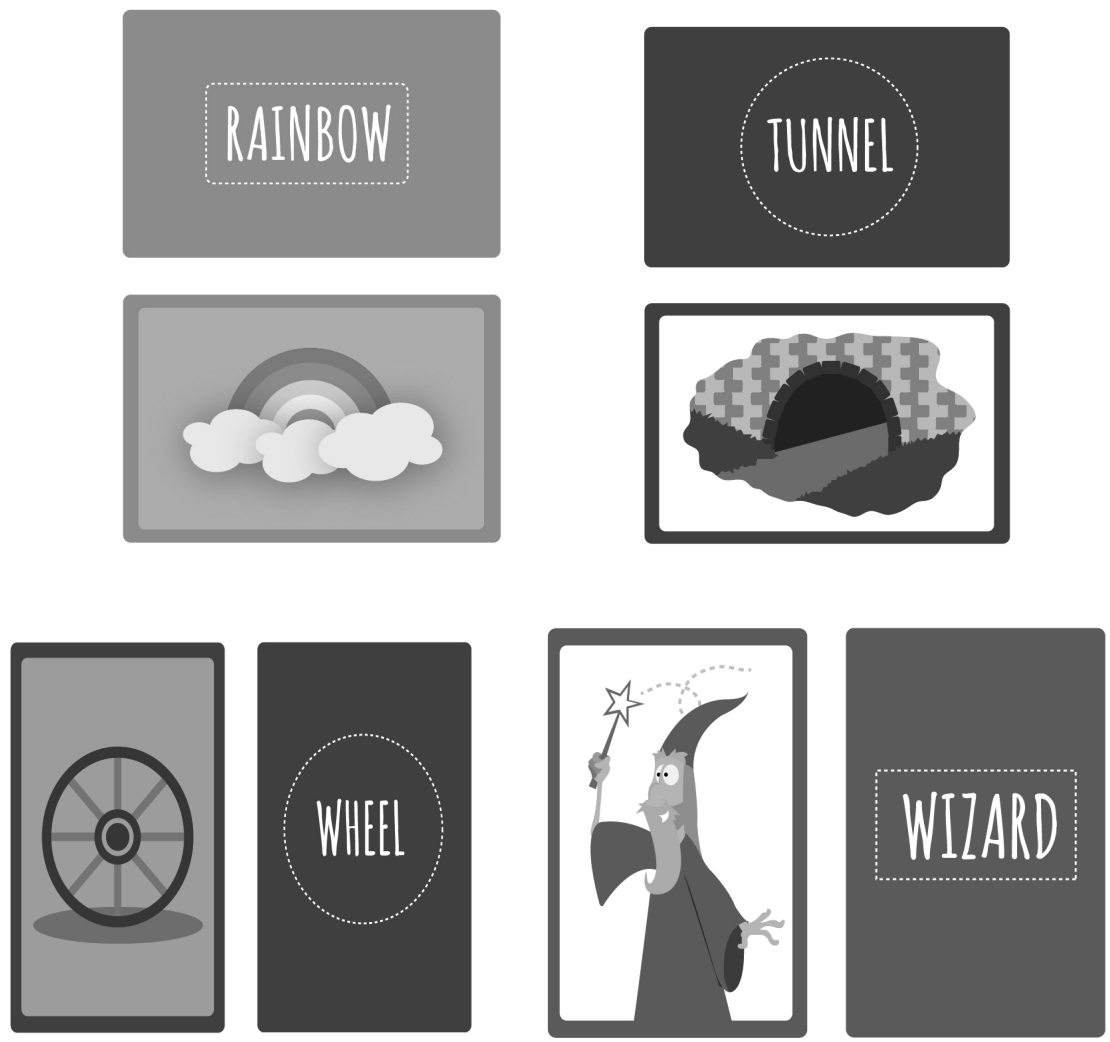

2. The students will write a story in their notebooks using the flashcard words, as many as possible.

\section{While-listening:}

The students are going to watch the chapter "A missing piece". It lasts half an hour approximately.

1. While they are watching the chapter, I will stop the play in some parts. Then, the students will repeat the character's words.

\section{Post-watching:}

1. Comprehension activities. The students have to circle the correct one.

- Who is the friend who goes with Dora in the adventures?

a) a crocodile 
b) a monkey

c) a chicken

- What was missing at Tico's car?

a) a seatbelt

b) a steering wheel

c) a wheel

- What obstacles do they have to pass to find the magic wand?

a) a crocodile swimming pool, a black tunnel and a rainbow

b) a crocodile lake, a red tunnel and a rainbow

c) a crocodile beach, a red tunnel and a rainbow

- Where is the magic wand finally?

a) in a golden box

b) in a golden pot

c) in a golden cup

2. Theatre representation

The students will go to the blackboard in groups. They will represent the chapter "the missing piece".

WIZARD: I have lost my magic wand. Can you help me to find out?

DORA and BOOTS: Yes, we will find out.

NARRATOR: Dora and Tico have to cross a crocodile lake, through the red tunnel and arrive at the end of the rainbow.

DORA: Something is missing...

BOOT: We need a backpack, a sock, a wheel...

DORA: Look! Tico is there. Can we go in your car Tico?

TICO: Of course!

NARRATOR: In the tunnel...

DORA: Oh no! There is a bus. Say STOP. (Audience will say STOP)

BUS: I'm really sorry.

NARRATOR: At the end of the tunnel...

BOOT: Thanks Tico. 
TICO: You're welcome.

DORA: Look! There is Isa la Iguana, can we go in your rocket, Isa?

ISA: Oh! Yeah! Put the helmets!

NARRATOR: They arrive at the rainbow.

WIZARD: Oh! My magic wand! Now you can finish the puzzle.

DORA AND BOTAS: We did it! (Dancing)

WIZARD: Thank you. And now, I will give you some presents with my magic wand.

EVERYBODY: YES!! We did it! (Happy and dancing)

After all the representations, the students will vote the best performance.

\section{B) POCOYÓ}

The students are going to watch a chapter of the cartoon Pocoyó. The chapter is called

"A little something between friends". It lasts 7:13 minutes.

\section{Pre-watching:}

1. The students are going to review vocabulary about toys. First, I will describe the objects and the students will try to guess them. Then, each student will describe one object and the rest of the class will guess it. (ball, castle, clock, telephone, train, watering can...)

\section{While-watching:}

Afterwards, the students will watch the chapter "A little something between friends".

1. I will stop the chapter in different parts and will ask the students what they think that is going to happen.

\section{Post-watching:}

1. Unite the adjectives with Pocoyó's faces.

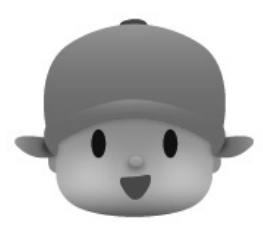

ANGRY

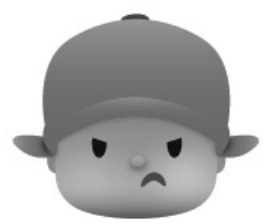

FUNNY 


\section{SURPRISED}
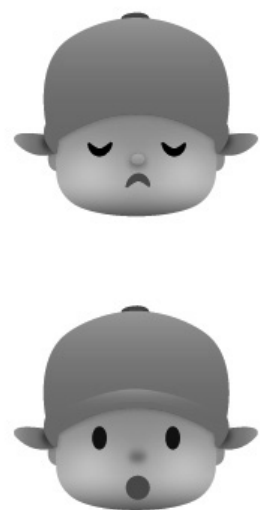

\section{HAPPY}

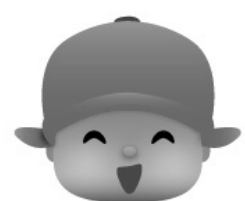

SAD

2. The students have to write the plot of the story. There are some vignettes and they have to write what has happened in each one.

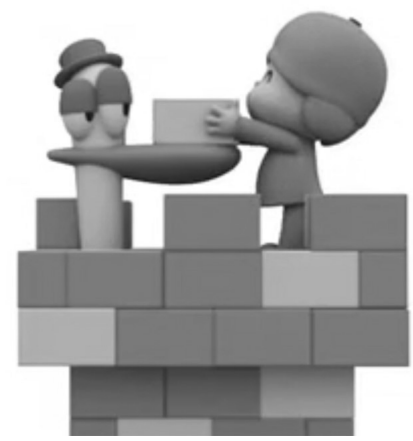

1. 


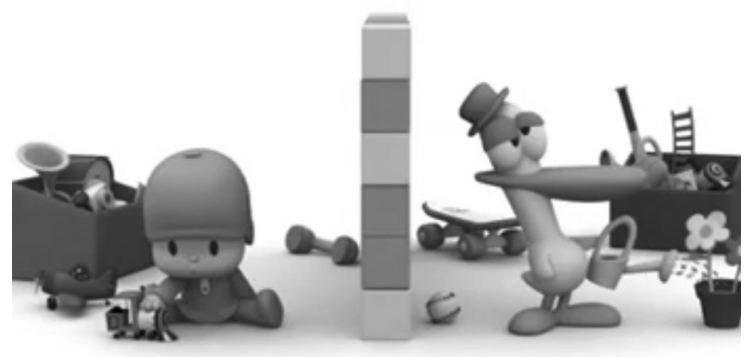

2.

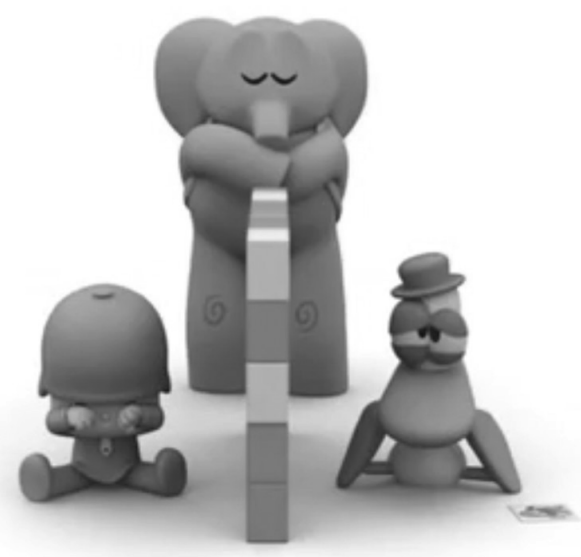

3 


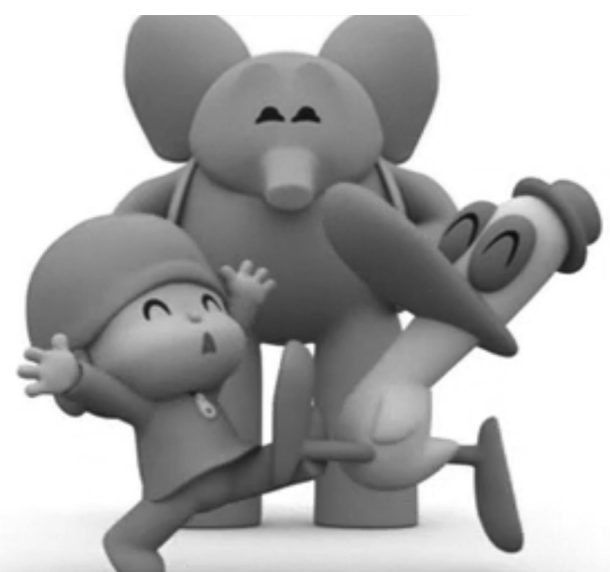

4.

\section{C) PEPPA PIG}

The students are going to watch a chapter of the cartoon Peppa pig. This chapter is called "Peppa goes shopping". It lasts 5:00 minutes.

\section{Pre-watching:}

1. I would review vocabulary and pronunciation of fruits and vegetables (apple, melon, orange, pear, tomato, carrot, lettuce, pepper...).

\section{While-watching:}

1. The students will do a word search activity about animals. They will mark the name of the animal that they heard.

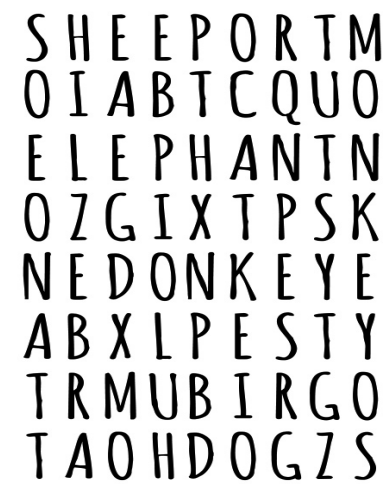




\section{Post-watching:}

1. I will give a worksheet with four photos to each student. On the photos will be shown a pizza, a salad, a fruit salad and a Spanish paella. The students have to guess the products used to make these dishes.
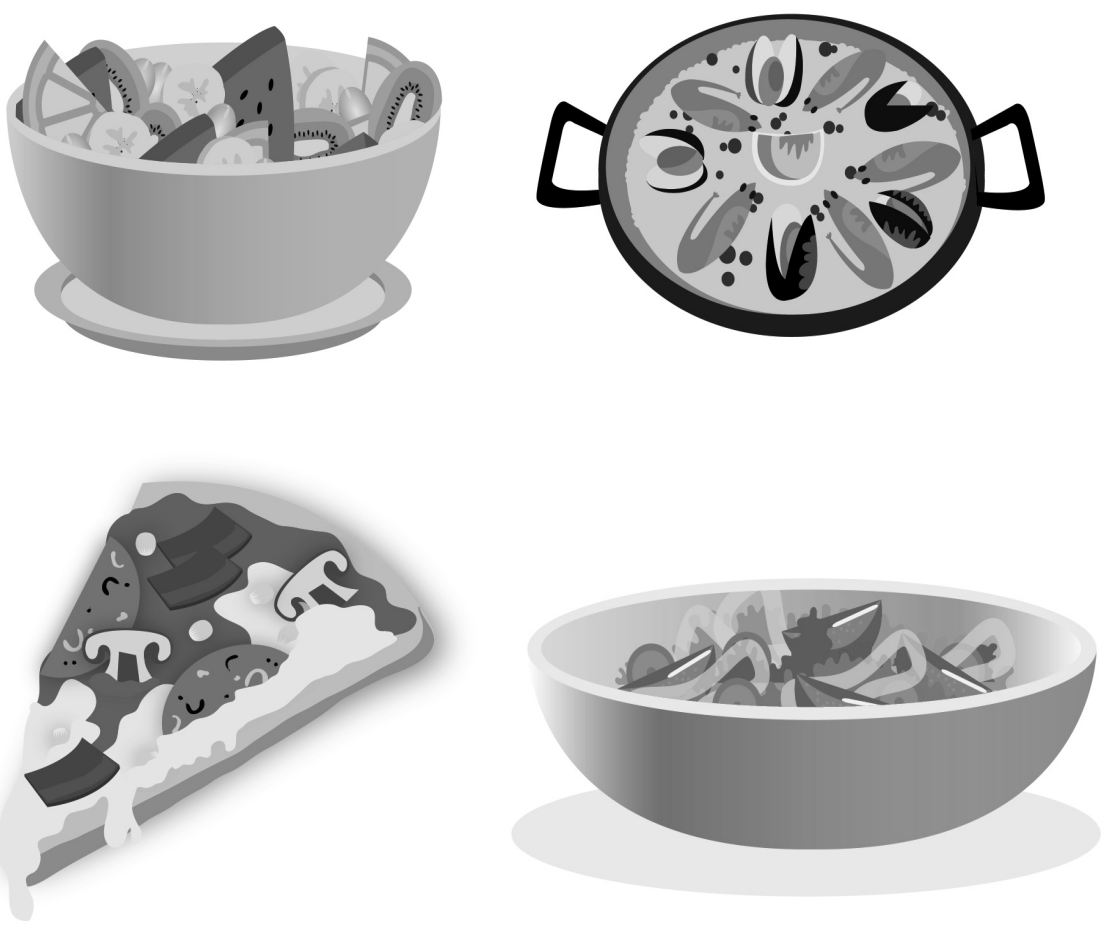

2. The students are going to play bingo in a different way. I will give a bingo card to each student. They have to write down one name of fruits or vegetables in the each box. I will say loudly a word, for example "orange". The student, who has written this word in one of his boxes, will cross out the word on his bingo card. The game continues until a child says bingo. The winner will be the first who has all the words crossed out. 

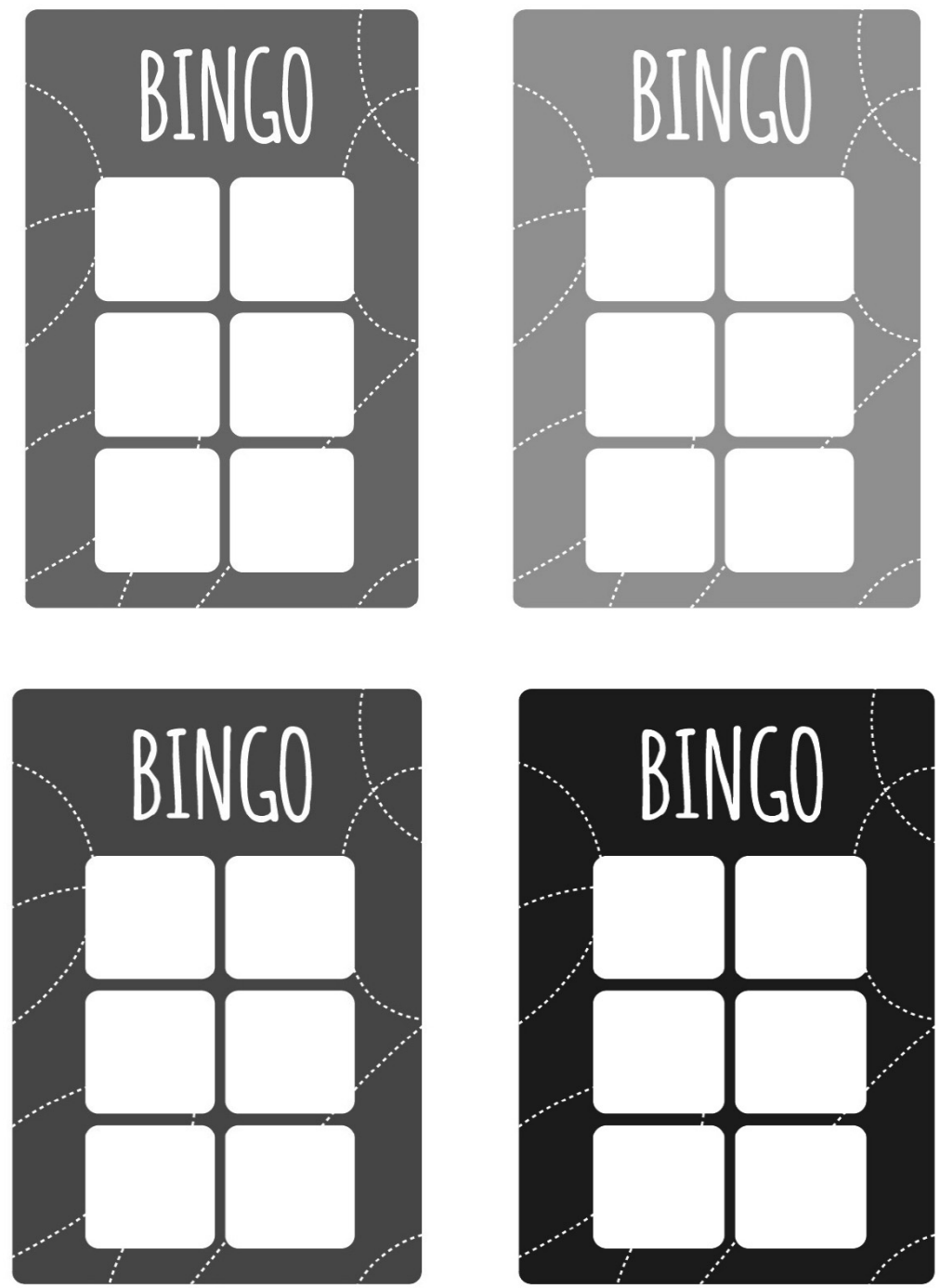

3. Students are going to do a role-play of Peppa Pig (Peppa goes shopping). Some students play the role of shop-keeper and other students play the role of the family members (buying fruits and vegetables). Go through a number of times swapping roles of the students.

\section{CONCLUSIONS}

To summarize the need for updating and keeping relevant the methodology of teaching, such as playing songs and showing cartoons, it helps motivate children in new and challenging ways. It helps show students cultural diversity through the use of authentic 
material. My idea is to show didactic resources and to propose some activities that can be used with listening songs or watching cartoons. The aim is that children learn new vocabulary, expressions, other accents, different manners of speaking English, thanks to current famous music groups and popular cartoons. The following ideas and conclusions emerge from my proposals:

-There are various activities which promote the learning of a second language.

-New vocabulary can be introduced.

-The students work with real materials and authentic language that they know and which is familiar.

-Songs and cartoons can be selected to suit the needs and interests of the students.

-Grammar and cultural aspects can be introduced through songs and cartoons.

-My proposal can be related with other areas of learning, because the students sing, dance, draw, play games, use the Internet.

-All communicative skills are developed through songs and cartoons

-Listening to popular songs pupils will enrich their English music culture.

-Teaching methods, more particularly humanistic ones, are used in the exploitation of songs and cartoons in the foreign language classroom.

-These resources promote the learning in a motivated and relaxed way.

I am confident that children will be motivated and enjoy these activities in the foreign or second language classroom. Lessons have evolved from the more traditional passive approach of years gone by to engaging students in a variety of different active styles that takes in the differing learning needs of the students. When you use this methodology, it will not only improve your classroom interactivity, but also the students will continue to use and learn outside of the classroom and transfer into everyday situations as to what they have learnt inside the classroom environment.

\section{REFERENCES}

Alburquerque, R. 1990. En el aula de Inglés. London: Longman.

AlCARAZ Varó, E. et al. 1992. Enseñanza y aprendizaje de las lenguas modernas. Madrid: Ediciones Rialp.

BARRIOS EsPINOSA, M.E. 2007. La utilización de material de video en la clase de inglés de niños de corta edad. Málaga: Universidad de Málaga.

Brewster, J. 1992 The Primary English Teachers Guide. London: Penguin.

Brown, H.D. 2000. Teaching by Principles. USA: Pearson ESL.

Byrne, D.1989. Teaching Oral English. London: Longman.

CAmbre, M.A. et al.1992. "Implementation of generative learning principles in interactive video using repurposes video materials". Journal of Visual Literacy 12 (12-1:35-56) Ohio University.

COUNCIL OF EuROPE. 2001. European Common Framework of Reference for Languages. Learning. Teaching. Assesment. Cambridge: Cambridge University Press. 
Cranmer, D. and Laroy, C. 1992. Musical Openings. Using Music in the Language Classroom. Harlow: Longman.

DAKIN, J. 1968. Songs and Rhymes for the Teaching of English. Harlow: Longman.

Edwards, J.C. 1997. Using Music for Second Language Purposes. California: University of California.

Fonseca Mora, C. 1999. El papel de la musicalidad del lenguaje en el proceso de adquisición del inglés como segunda lengua. Huelva: University of Huelva.

Griffee Dale, T. 1992. Songs in Action. London: Prentice Hall.

González de Castejón, M.L. 1989. Lend songs an ear. Granada: Servicio de Publicaciones de la Delegación Provincial de Educación y Ciencia de Granada.

HAN, H. 1994. Implementing the video-based instruction in the college-level ESL classroom based on second language acquisition and communicative competence theories. Carolina: University of Carolina.

HANLEY, J. B. et al. 1995. "Using video as an advance organizer to a written passage in the FLES classroom". Modern Language Journal (79-1:57-66).

Harmer, J. 2007. How to teach English. London: Pearson.

Herron, C. And Tomasello, M. 1992. “Acquiring grammatical structures by guided induction”. The French Review (65-5: 708-718) April.

Holmes, Vicki L. and Moulton Margaret R. 2001. Writing Simple Poems. Cambridge: Cambridge University Press.

KERRIDGE, D. 1982. The use of video films. Video in the Language Classroom. London: Heinemann.

Madrid Fernández, D. et al. 1990. Posibilidades didácticas de las canciones en la clase de inglés. Granada: Servicio de Publicaciones de la Delegación Provincial de Educación y Ciencia de Granada.

---. 2004. TEFL in Primary Education. Granada: University of Granada.

Mata BARREIRO, C. 1990. Las canciones como refuerzo de las cuatro destrezas. Madrid: Aula XXI.

MeKHeIM, A. 2011. "The impact of using videos on whole language learning in EFL context." Arab World English Journal 2, (2:5-39) University of King Khalid.April http:// www.awej.org/index.php?option=com content\&view=article\&id=40:the-impact-ofusing-videos-on-whole-language-learning-in-efl-context\&catid=16\&Itemid=115

MorleY, J. 1981. "Using films and videos as English language instructional materials: theoretical principles and pedagogical practices”. Ndong-Ekouaga: Languages, Linguistics, and Literature.

Muros, J. Et al. 1998. Music through English. Granada: Grupo Editorial Universitario. 
Murphy, T. 1990. Song and Music in Language Learning. An Analysis of pop song lyrics and music in teaching English to speaker of other languages. Berna: Peter Lang.

---. 1992. Music and Song. Oxford University Press: Oxford.

Olivares Merino, J.A. 2002. "Song and other ways of retention: exploiting musical and visual modes of learning in the classroom". Uso del inglés en el aula: lengua, literatura y traducción. (1: 167-183) Jaén: Universidad de Jaén.

Robinson, B. 1986. “Once upon a tune...” Aula de inglés 3:6-8. Granada.

Secules, T. et al. 1992. "The effect of video context on foreign language learning". Modern Language Journal, 76,4: 480.490. Winter. USA.

Strachey Bussy, D. 1950. Fifty Nursery Rhymes. With a Commentary on English Usage for French Students. París: Gallimard.

Swaffar, J. And Vlatten, A. 1997. "A Sequential Model for Video Viewing in the Foreign Language Curriculum”. The Modern Language Journal, 81(2): 175-188. USA.

TERrELL, T.D. 1993. "Comprehensible input for intermediate foreign language students via video". Language Learning Technologies 26, 2: 17-23. September. USA.

WEN, C, 1989. "Student attitudes during a course with and without TV in the language laboratory". Educational Media and Library Sciences, 26-3:238-250.April. Taiwan.

Williamson, J. 1989. A new look at using songs. Granada: Servicio de Publicaciones de la Delegación Provincial de Educación y Ciencia de Granada.

Coldplay: "Every teardrop is a waterfall" (song-2011)

Dora the explorer: "The missing piece" (chapter $2 \times 4$ )

Jedward: "Bad behaviour" (song-2011)

Madonna: "Superstar" (song-2012)

Peppa Pig: "Peppa goes shopping” (chapter 49x1)

Pocoyó: "A little something between friends" (chapter 51x1)

\footnotetext{
* All the activities, pictures and the crossword have been designed by Natalia Lucía Vélez Gea
}

* All the pictures and the crossword are drawn by Guillermo Rodríguez García 